\title{
Gender Perspective in Customary and Islamic Inheritance Law
}

\author{
Retnowulandari Wahyuni \\ \{wahyuni.r@trisakti.ac.id\} \\ Universitas Trisakti, Jakarta, Indonesia
}

\begin{abstract}
The reality of the heterogeneous history of the Indonesian nation and society has made the inheritance law system in Indonesia plural, consisting of customary, Islamic, and Western laws. The problem is that in the provisions of customary law and Islamic law there are differences in inheritance for women, especially in societies with patrilineal customary kinship systems, even if they are Muslim families, generally, they still carry out the laws that live in their communities. So that in the event of a marriage breaking up due to death, there is no protection for the inheritance even though in CEDAW, gender equality has been declared. This normative research is descriptive and the analysis is done qualitatively. The results of this study indicate that Islamic inheritance law which is God's law cannot be changed, and patrilineal customary inheritance law is still difficult to change, although there are several court decisions related to customary and Islamic inheritance law that has shifted. So for the enforcement of legal equality, judges are needed who are responsive and have a gender perspective.
\end{abstract}

Keywords: customary inheritance law; Islamic inheritance law

\section{Introduction}

Indonesian inheritance law is undoubtedly plural due to Indonesian heterogeneity. The law cannot be unified because the law system is formed by many influences such as Dutch colonial law that was practiced for three and a half-century, Islamic law that enters Indonesia in the seventh century, and Indonesian indigenous law which is made from a multicultural system. Based on that, cultural, religious (Islamic), and western laws are very much rooted and act as a part of private law implemented in Indonesia. The difficulty to unify these three law basics have only enabled unification only on neutral subjects such as economy, trading, labor, and criminal law due to historical, pluralism, multiculturalism, and globalization reasons as mentioned by Lord Radcliffe [1]:

"you will not mistake my meaning or suppose that I depreciate one of the great humane studies of I say that we cannot learn the law by learning law. If it is to be anything more than just a technique it is to be so much more than itself: a part of history, a part of economics and sociology, a part of ethics and a philosophy of life."

The difficulty to unify inheritance law is also because most Indonesians are Moslem and they practice Islamic law as their positive law, especially regarding inheritance cases. As 
understood by Moslem, inheritance shares between men and women are regulated in the AlQur'an Surah (hereinafter abbreviated into Q.S.) An-Nisaa verse 11 "Allah prescribes for you about (the division of inheritance for) your children. That is: the share of a son is equal to the share of two daughters... "In this verse, it is clearly stated that the inheritance shares between men and women are regulated based on the heir's position concerning the deceased (mayyit). The verse is categorized as qath'i tsubut and dilalah verse. Qath'i tsubut means to come from a clear source which is the Al-Qur'an and Hadits mutawatir. Meanwhile, qath 'i dilalah means that the verse clearly states its definition with no further explanation required to understand it. Based on that, when a Moslem deliberately denies qath'i dilalah and tsubut verse he is considered a blasphemer and apostate from Islam. Islamic scholars agree that this mawarits verse is categorized as qath'I tsubut and dilalah verse, which makes any effort to dispute the verse (ijtihad) is unavailable; la ijtihada ma wujudin nash, which means that Islamic inheritance law is based on Ijbari ground (compelling Muslim to implement inheritance regulation as it is); the provision is clearly explained in:

Q.S. An-Nisaa':13 [2] “...Whoever obeys Allah and His Messenger...” means that the person does not add or reduce inheritance allocation with certain illegal tricks or any other ways but set it according to the inheritance regulation determined by Allah Subhanahu wa Ta'ala, "Surely Allah will enter him into Paradise in which rivers flow, while they live in it forever; and that's a big win. And whoever disobeys Allah and His Messenger and violates His provisions, Allah will surely admit him to the Hell-fire while he abides in it and for him is a humiliating torment." (Q.S. An-Nisaa':14) [2].

This means that any disobedience towards Allah and His laws driven by the unwillingness to utilize laws determined by Allah will be punished with a very painful punishment." The situation makes it impossible for Moslem that understands inheritance law to disobey the law that has been clearly stated in the Al-Qur'an or another word, there is no choice for Moslem besides to abide by the law.

A similar situation is also happening on custom inheritance law. The position of custom inheritance law is similar to Islamic inheritance law practiced by Moslem, for example, inheritance law practiced by the people of Karo Moslem ethnic group that still embraces Karo custom law with its patrilineal system [3]. The wives are not eligible to receive an inheritance from their passing husbands but still can receive benefits from their wealth as long as they are not remarried. Meanwhile, the deceased sons will only get their inheritance share when the widowed mothers pass away, and the daughters will only receive an inheritance in form of gold jewelry. In a matrilineal genealogical society, women should receive more benefits than men in terms of inheritance. However, in Minangkabau ethnic group, the women are only able to enjoy and preserve inheritance but the amount of shares is subject to the decision of ninik mamak (elders who are men). The same situation occurs in Javanese bilateral society that unevenly divides inheritance (gono gini) between men and women by following segendong sepikulan system that allows men to receive two parts and women to receive one part. In the meantime, CEDAW convention held on July $24^{\text {th, }} 1984$ based on the implementation of Indonesian Republic Law Number 7 the Year 1984 on Convention Ratification on the Elimination of All Forms of Discrimination Against Women, regulates that both the government and the people of Indonesia must abide by the law.

\section{Research Problems}


Based on the discussion above, it is appealing to study whether Indonesia can reform its inheritance law by including gender perspective remembering that the plural Indonesian inheritance law is unlikely to be unified, and the effort to ensure that Indonesian inheritance law can provide the requirements to provide gender equality.

\section{Research Methods}

By using a normative research method which includes research on the principles of customary inheritance law and the rights of indigenous peoples and women's rights this research is analyzed qualitatively because this research is only descriptive [4]. The legal material used is the principle of Islamic inheritance in the provisions of the Compilation of Islamic Law (Inpres no. 1 of 1991) and norms in the interpretation of the Qur'an and Hadith regarding inheritance for Muslim women, as well as the principles of customary inheritance law from patrilineal, matrilineal, and bilateral genealogical kinship systems, and the Convention on the Elimination of all Forms of Discrimination Against Women (CEDAW), which has the principle that the state has an active obligation to implement substantive equality and non-discrimination against women, based on the data analyzed to answer the problem of this research.

\section{Discussion}

\subsection{Custom and Islamic Inheritance Laws in Indonesia Based on Gender Perspective}

Gender perspective that poses equality between men and women is difficult to be accepted by custom law on every cultural group in Indonesia, especially the ones that fanatically follow their custom more than their religions, as shown by the people of Moslem Karo and Minangkabau with their Adat basandi syara, syara basandi Kitabullah concept, although their custom law is practiced more than their religious law and with the event of Padri war that occurred to alter inheritance law for the people of Minangkabau. It is evident that in reality, the people still obey/fear/submit to custom law in Karo and Minangkabau ethnic groups, although they also admit to submitting to Islamic law. Based on research by [3], the people of Karo still implement their custom inheritance law instead of Islamic law although they admit that they are also Moslem. Based on Karo inheritance law, at the time of death, the oldest wife of the deceased will be given full control over the wealth of her husband until they are remarried. This is different than Islamic law which mentions that in the time of death, the inheritance must be shared after the wealth is free of debts to the heirs (parents if they are still alive, husband/wife, and children) [2].

Similarly, inheritance share amount is also divided based on patrilineal Karo custom law that prevents women (wives) from receiving any inheritance shares but is allowed to take benefit or to enjoy the inheritance until they are remarried, except for divorced wives before the time of death who receive nothing from the inheritance. Inheritance portion or amount of share is hardly known in Karo custom inheritance law, which is different than any other ethnic groups that divide the inheritance with strict mathematical calculation. This means that even though inheritance law recognizes equal inheritance division, it doesn't mean that every heir will receive an equal portion and women are not receiving the inheritance. However, lately in practice, the people of Karo have already considered Islamic law in their inheritance division 
by including women although the portion is still not abiding Islamic law and only enable women to receive little from the inheritance in form of money and gold jewelry, and the wives to enjoy their late husbands' wealth until they are remarried (cannot be expelled by the husband's family). Unfortunately, by the time of this research in 2014, the fact shows that females of Karo are still unable to receive an inheritance but a small amount, and their rights as Moslem are still unfulfilled. For the last 20 years, the problem that prevents women to receive the inheritance as found in Karo becomes national consideration after on October $23^{\text {rd, }}$ 1961 the disputed parties file a case to the District Court of Kabanjahe regarding inheritance for women that leads to Supreme Court Decision No. 179/K/Sip/1961 that refuses cassation posed by plaintiff and decide that the women (in the disputed case) have a similar position with the men regarding their parents' inheritance. This Supreme Court Decision can be said as an effort from the government to equally provide the rights both for men and women to receive an inheritance in genealogic bilateral/parental society. According to John Bowen in his book Islam, Law, and Equality in Indonesia [5] and Subekti, this event is seen as a historical point to reach equality of men and women, as a law that moves and lives according to the will of Indonesian people. This shows another fact that custom law has been moving dynamically towards society structure that emphasizes core family (somah) concept, but this concept is yet to be accepted and still produce pros and cons in the society of Kabanjahe, and most of patrilineal society in Indonesia.

Similarly, the people of genealogical matrilineal of Minangkabau concerning inheritance law are still practicing collective custom inheritance law system. The system is one of the primary aspects that characterize Minang Society identity. Their culture and custom are appointing women as the center of heirs and kinship lines. Kinship is referred to mother bloodline which is known as Samande (one mother) concept. Meanwhile, the fathers are known as Sumando (in-laws) and treated as guests in their families. The women of Minangkabau possess a special position of Bundo Kanduang, which plays important roles to preserve family inheritance and determine the success of decisions made by men as mamak (uncle or brothers of mothers), and penghulu (tribal leader). This large influence from the women of Minang is symbolized as Limpapeh Rumah nan Gadang (the main pillar of the house). Even though the influence of economic power and inheritance control by women, the men of the women's family are still holding the authority or legitimate power towards their society.

Matrilineal is still maintained and practiced throughout generations by Minangkabau society but there is no custom punishment for those who do not obey the custom. Because of that, each Moslem individual in Minang tends to collectively submit their inheritance to the women and not to the men as regulated by Islamic inheritance law. This practice is conducted throughout generations until now. According to Tsuyoshi Kato in his dissertation [6], the matrilineal system will become stronger within Minangkabau society even though they are moving to cities outside Minang areas. Meanwhile based on research by Anwar Fauzi (2012) [7], on an interview with five Minang people in Malang City, the first is Datok A. DT. Tan Pahlawan (the leader of Minang Taboh Gadang Community Association (HIMATOS)) "regarding inheritance system according to Islamic law, Datok A. DT. Tan Pahlawan mentioned that the majority of Minangkabau society is Moslem, but in relation to inheritance distribution, the people of Minang society put forward their custom inheritance system (matrilineal) than Islamic inheritance law. This is a form of respect towards our ancestors." The second, Hendra (an employee of Padang culinary restaurant) asked a similar question, Mr. Hendra mentioned that "I do not fully understand about Islamic inheritance law, although I am a Moslem. This happens because of the strong community culture." Based on this data, it is 
proven that even though the majority of Minangkabau society is Moslem, they do not fully understand Islamic inheritance law because it is rarely applied in Minang society.

From a gender perspective, the people of Minangkabau custom society do not practice Islamic law on their inheritance system and emphasizes the role of women in their inheritance practice because of the position of bundo kanduang. However, based on gender perspective on inheritance, equality should not be provided for women but also for men, which in the case of Minang society are not included as heirs, although when they act as ninik mamak, they will become very powerful to determine the inheritance of the women family. Based on that, the movement of genealogical Minang Matrilineal society is not significant because the people who wander outside of Minang area are still practicing their custom law, despite the existence of a small group of people that already influenced by local custom.

The genealogical parental/bilateral society is another characteristic of local genius, local prudential, or local wisdom of Indonesia. It shows that Indonesian cultural richness is not easily diminished even though there is a strong cultural movement among Indonesian people, for example in Javanese society that mostly is Moslem that allows two options of inheritance distribution between men and women namely dum dum kupat/sigar semangka, which means men and women are subject to an equal amount of inheritance that commonly enabled on poor families. In this principle, the basis of inheritance does not include the perspective of men or women, but their economic capability to be independent.

The second way is to apply segendhong sepikul system, which means that men receive twice larger as women, as influenced by Islamic inheritance law which regulates that men should receive an inheritance ratio of 2 to 1 than women. There is also an uncommon model of inheritance distribution through discussion that allows the smallest child (anak ragil) to inherit their parents' house along with its content without seeing whether it is a man or woman [8]. A similar situation was also found in Bugis society of Enok Sub District. Out of many inheritance cases, the women are acting as main heirs that receive the inheritor house [9] because of their custom. It shows that custom regulation is still obeyed and the inheritance system does not always have to follow its genealogical or religious concepts and it depends on the custom practiced in certain areas.

It is undoubtedly that it doesn't matter how dynamic a custom law can be, the heterogeneity of Indonesian society will always lead to custom law plurality, which is unique on each part of society and has different characteristics. The customs is acknowledged by the country according to Indonesian Constitution 1945 Chapter $18 \mathrm{~B}$ verse (2) which is: "The State admits and respects custom society units and their traditional rights as long as the society exists and developed according to the principle of Indonesian Republic as regulated by law."

If we refer to religion regulation, especially Islamic inheritance law by seeing that the majority of Indonesian are Moslem, the fact that the existence of Islamic law in the $7^{\text {th }}$ century does not simply influence Indonesian custom laws, and if it is, the impact is insignificant. It shows that cultural fanatic is stronger than religious fanatic in Indonesia, which might be influenced by the Dutch colonial politic of divide and conquer (divide et impera) by placing custom law higher than religion law. Based on the theory of reception posed by Snouck Hogeronye, Terhar, and VanVollen Hoven the politic is still influencing Indonesian law culture up until now. Because of that, custom law still exists in Indonesian society that allows the patriarchal system to strongly influence Indonesian custom law except on parental genealogical society. Even though there is a movement towards somah concept in a court decision, the fact that in a patrilineal and matrilineal society, custom law is a strong part of their lives. This has made it difficult to implement CEDAW regulation to erase discrimination towards women in cultural society. 
In relation to Islamic law in Indonesian society that majorly are Moslem, the fact that there are groups of people that have wholly submitted to Allah provision and His messengers in compared to 30 years ago. However, in reality, a lot of Indonesian people do not understand faraidh law, and instead, drive them to practice what they understand such as cultural values as described above. There may be a small number of people who understand Islamic law, but it is considered injustice because of larger portion for men than women with a ratio of 2 to 1 , although clearly stated in Q.S An-Nisaa 13-14 that literally, everyone that disobey inheritance law as posed in Al-Qur'an will be consumed by Hell-Fire for eternity. This means that the law is compelling (ijbar) and leaves Moslem with no other choices. The ratio of 2 to 1 for men in Islamic inheritance law is based on the obligation of men to fulfill their family needs (wives) as mentioned in the Al-Qur'an Q.S. An-Nisaa: 34 that the larger portion of inheritance for men is because the duty of men is heavier than women in the eye of Islam. This regulation is a progressive concept and based on proportionality in the context of Arabic people, where the responsibility of a family belongs to the men. That is why the inheritance received by men is larger than the ones received by women (Li al-dzakari mitslu hazhzh al-untsayain) [10].

Mahmud Yunus in his interpretation mentioned that the wisdom of Islamic inheritance distribution is that men should provide for themselves, their wives, and their children. The author adds that it also includes their parents as mentioned in Q.S At-Tahrim 66: 6 and Q.S. Luqman 31:14 [2] especially their mothers as mentioned by hadith. On the other hand, women are only subject to fulfill their own needs. When they are married, their needs will be provided by their husbands. That is why the inheritance portion of men is larger than women. Inheritance verse is a response from the Al-Qur'an towards the social construct of humanity, which shows injustice between men and women. With the revelation of the Al-Qur'an and the implementation by the prophet, women's rights are starting to be considered at the time. Moreover, at present time, most women are forced to replace their husbands as a provider in their families. Because of that, from the author perspective, Islamic inheritance law as regulated by the Almighty has included gender equality as mentioned in the Al-Qur'an Surah Al-Isra' 17:70 [2] "Indeed, We have honored the children and grandchildren of Adam (humans), We carried them on land and at sea, We provided sustenance from the good things and We gave them perfect advantages over most of the creatures We have created." Based on that, it is clear that the Al-Qur'an does not differentiate men and women, but placed them under equal positions except for their biological and reproduction functions. Besides that, according to Islamic sharia, Allah and His Messengers have already uplifted women regarding inheritance; free them from every kind of slavery, including discrimination that happened towards women in every aspect of life. Islam has uplifted women's rights to be equally positioned as men as mentioned in Q.S. Al-Hujurat Chapter 49 verse 13 [2], "O mankind, We have created you from male and female and We have made you into nations and tribes, so that you may know one another. Verily, the most honorable of you in the sight of Allah is the most pious."

This verse clearly illustrates human servitude towards Allah SWT. By acknowledging servitude towards Allah SWT, every human, both men, and women are equaled (egalitarian) in the face of Allah and only differed by their levels of piety, which makes Islamic justice a certainty. Because Islam obligates men as providers as mentioned in Al-Qur'an An-Nisaa 34, men receive more of the inheritance than women. Based on this fact, the author considers that inheritance should be distributed progressively both in case of death or divorce with just/gender equality concept and proportionately follow the rights of the heirs. Inheritance concept as expected by gender equality concept as proposed in CEDAW sees that every human should receive equal and indiscriminate treatments without looking at their natural 
genders.

Based on the description above, it is clear that dynamic custom law in Indonesia will not naturally happen as expected by the society, as it does not affect by the influence of God even though in religion, men and women are not differed except for their functions, where men are burdened with extra obligations as providers, which makes them more rightful than women in term of inheritance distribution (proportional justice). In an abnormal situation, Islam still opens a chance to discuss inheritance by taking Al-Qur'an as guidance so that justice can be felt by every part of the society without differentiating their gender.

In the effort of inheritance law reformation, custom and religious laws are the strongest and the most fundamentally obeyed laws. That is why, although Lord Radcliffe's theory is quite old, the author agrees with the theory which mentions that law unification is pretty difficult in the field of private law, especially when it is faced with custom and religious laws. Based on that, even though Indonesia has already ratified CEDAW that prevents discrimination against women, the actual implementation is quite difficult because the society tends to apply custom and religious law (in terms of inheritance distribution). After all, the practice is already fundamentally rooted in society.

\subsection{Law Efforts Available to Ensure Gender Equality in Indonesia Inheritance Law}

The effort to ensure national inheritance law implementation that considers gender equality is a challenge with numerous difficulties. To implement it, a peace effort (islah) and national legislation of inheritance law are vital, which is also difficult to be implemented in a religious and traditional society. The fact is that the court of law should be progressively operated, but this type of jurisprudence is uncommon as the one that happened in the District Court of Kabanjahe regarding women inheritance case in patrilineal society with Supreme Court Decision No. 179/K/Sip/1961 that allows an equal amount of inheritance distribution for men and women. There is also a fact that most Indonesian does not understand their inheritance law so they submit to tribe leaders' decision as to the right decision as happened in Minangkabau society that depends on the decision of Ninik mamak even though the majority of them are Moslem that uphold "adat basandi syara', syara' basandi kitabullah" concept. The fact is that they are unaware of the sharia law that regulates inheritance. The people who moved out from the area of Minangkabau and live abroad do not practice Islamic inheritance law and tend to utilize local custom law as exampled by the research of Anwar Fauzi in Malang [7]. In reality, as Moslem, Allah has prepared a detailed, thorough, and compelling inheritance law to avoid them from taking any other choices (ijbar) to ensure human safety. However, because a lot of Moslem people do not understand inheritance law, they tend to practice the wrong regulation to distribute the inheritance.

The effort to unify/codify national gender-based inheritance law might be available with the existence of political will in the House of Representatives. However, specific unification will be difficult and will still be plural as Marriage Law No.1 of 1974. It is also possible that society avoids utilizing the law because it cannot act as living law and if faced with religious society, they will still practice their religious law. According to Lord Radcliffe, law science is a part of history, economy and sociology, ethics and living philosophy of the society that formed Indonesian law from Dutch colonial occupation, the penetration of numerous religions and social-cultural values, and the ethic of Indonesian society which is Pancasila; that upholds diversity as national richness and identity. Inheritance law unification is also rather difficult because a lot of Indonesian are unaware of the law, both national and religious law except the 
ones implemented in their cultural lives. Even in general, Indonesian people tend to question their religious law if considered injustice.

\section{Conclusion}

It can be concluded that cultural and Islamic inheritance laws in Indonesia as private laws of heterogeneous society are difficult to be unified into a gender-based inheritance law. It is substantially difficult because of the cultural diversity of the society. That is why the most possible way is to conduct a progressive court to determine inheritance law, whether it is custom inheritance law or Islamic inheritance law according to their preferences, but with consideration of women to ensure gender equality.

\section{References}

[1] Lord Radcliffe, The Law and Its Compass. Illinois: North Weistern University Press, 1962.

[2] “Al Qur'an.” https://quran.kemenag.go.id/.

[3] A. A. Tarigan, "Pelaksanaan Hukum Waris Pada Masyarakat Karo Muslim Di Kabupaten Karo," UIN Sumatera Utara, 2014.

[4] S. Soekanto and S. Mamudji, Penelitian Hukum Normatif. Jakarta: Raja Grafindo Persada, 2011.

[5] J. R. Bowen, Islam, Law and Equality in Indonesia: An Antropology of Public Reasoning. Cambridge: Cambridge University Press, 2003.

[6] T. Kato, Adat Minangkabau dan Merantau dalam Perspektif Sejarah. Jakarta: Balai Pustaka, 2005.

[7] A. Fauzi, "Dualitas Hukum Waris Minangkabau Dan Islam (Studi Konstruksi Sosial Masyarakat Muslim Minangkabau Di Malang)," Jurisdictie, vol. 3, no. 1, pp. 45-54, 2012, doi: 10.18860/j.v0i0.2180.

[8] A. Vela, "Pembagian Waris pada Masyarakat Jawa Ditinjau dari Hukum islam dan Dampaknya," As-Salam, vol. 4, no. 2, pp. 67-91, 2015, [Online]. Available: https://ejournal.staidarussalamlampung.ac.id/index.php/assalam/article/view/74.

[9] D. A. P. Sihombing, "Pembagian Waris Adat Masyarakat Suku Bugis di Kecamatan Enok, Kabupaten Indragiri Hilir, Provinsi Riau," Universitas Sumatera Utara Medan, 2017.

[10] R. Khariroh, "Islam dan Hak Waris Perempuan dalam Konteks Keindonesiaan," 2018. https://swararahima.com/2018/08/24/islam-dan-hak-waris-perempuan-dalam-kontekskeindonesiaan/ (accessed Dec. 21, 2020). 